$\underline{\xi}=-m$

\title{
Defensive role of silibinin against arsenic induced oxidative stress mediated dyslipidemia and neurotoxicity in rats
}

\author{
M. Muthumani ${ }^{1}$, Nc.Sumedha ${ }^{1}$, K. Shagirtha ${ }^{2}$, S. Milton Prabu ${ }^{1 *}$ \\ ${ }^{1}$ Department of Zoology, Faculty of Science \\ ${ }^{2}$ Department of Biochemistry, St.Joseph 'scollege, Cuddalore, Annamalai University, Annamalainagar608002Tamilnadu, India \\ *Corresponding author E-mail:smprabu73@gmail.com
}

\begin{abstract}
Arsenic (As) is an environmental toxic metalloid that is present in everywhere such as air, water and soil. Generally, inorganic arsenic has a tendency to be more toxic than organic arsenic. The present study was designed to determine whether oral administration of silibinin (SB), which has been shown to have substantial antioxidant properties, when pre-administered ( $75 \mathrm{mg} / \mathrm{kg}$ body weight) once daily for 4 weeks along with arsenic $(5 \mathrm{mg} / \mathrm{kg})$ would prevent arsenic-induced changes in antioxidant defense system, superoxide dismutase (SOD), catalase (CAT), glutathione peroxidase (GPX), glutathione-S-transferase (GST), glutathione reductase (GR), glucose-6-phosphate dehydrogenase (G6PD), reduced glutathione (GSH), total sulfhydryl groups (TSH) and vitamin $\mathrm{C}$ in rat brain regions such as cortex, striatum, cerebellum, hippocampus and brain stem. Our study also examined the effect of SB over arsenic-induced reactive oxygen species (ROS) production and lipid peroxidation level (LPO) and protein carbonyl content (PC) in distinct brain regions of rats. Moreover, As also alters the lipid profiles such as total lipids, phospholipids, cholesterol, cerebrosides and gangliosides in various regions of the brain. Pre-administration of SB restores the altered enzymatic and non-enzymatic antioxidants, lipid profiles and also markedly reduced the ROS, LPO, PC and accumulation of As in various regions of the brain. These results suggested that arsenic-induced deficits in antioxidant enzyme activities and increase in ROS production and lipid peroxidation levels in brain regions can be remarkably prevented by pre-administration of SB.
\end{abstract}

Keywords: Arsenic; Oxidative Stress; Brain; Lipid Profile; Silibinin; Rat.

\section{Introduction}

Arsenic (As), a Group I carcinogen (International Agency for Research on Cancer (IARC), 1989) and an environmental pollutant, has been implicated in the occurrence of various cancers and numerous health problems (Yoshida et al., 2004). High levels of inorganic arsenic are found in ground water in many regions of the world as a result of geochemical processes posing serious chronic health risks to humans (Yadav et al., 2009; Brinkel et al., 2009). Arsenic exposure has been associated with health problems, including hypertension (Yadav et al., 2009), cardiovascular diseases, developmental abnormalities, diabetes, hearing loss, fibrosis of the liver and lung, hematological disorders, neurological and reproductiveproblems, blackfoot disease and cancer (Kapaj et al., 2006; Khan et al., 2006). Moreover, peripheral neuropathy following arsenic toxicity has been reported (Kapaj et al., 2006; Vahidnia et al., 2007).

In view of the adverse effects of arsenic on brain, extensive studies have been undertaken to understand the mechanisms of arsenic-induced neurotoxicity. Enhanced generation of reactive oxygen species (ROS) and nitrogen species (RNS) associated with a deficient antioxidant system leading to increased oxidative stress is largely accepted as one of the potential mechanisms of arsenic neurotoxicity (Flora and Gupta, 2007; Shila et al., 2005a; Sinha et al., 2008a; Das et al., 2010) results in damage to mitochondrial membrane and subsequently to cell death. Involvement of neuronal nitric oxide synthase (nNOS) and nitric oxide (NO) levels has also been shown in arsenic neurotoxicity (Chattopadhyay et al., 2002; Zarazua et al., 2006; Flora et al., 2009; Rios et al., 2009).

Further, brain is a soft target of arsenic toxicity since it easily crosses the blood-brain barrier (Rosado et al., 2007; Brinkel et al., 2009). A number of studies have shown vulnerability of corpus striatum, Cerebellum,Brain stem,cortex and hippocampus to arsenic toxicity that are associated with behavioral and neurochemical abnormalities (ShilaEt al., 2005b; Yadav et al., 2009). Furthermore, arsenic also alters the contents of lipid classes, proteins, glutathione and the ascorbic acid in various regions of brain (Haider and Najar, 2008) Due to increasing exposure to environmental neurotoxicants like arsenic, there is an increasing interest to investigate the prophylactic and protective efficacy of natural products found in plant extracts. Silibinin (SB) is the major compound of the silymarin isolated from seeds of mediterranean milk thistle, Silybum marianum (L.) Gaertn. (Asteraceae), and clinically used as a hepatoprotectant (Pradhan and Girish, 2006). Silibinin (SB) has antilipoperoxidative activity with anti-inflammatory, anti-allergic and anti-oxidant activities by scavenging various free radicals (Basiglio et al., 2009). SB is reported to have a broad spectrum of biological activities such as hepatoprotective (Ferenci, 1989), antioxidant (Saller et al., 2001), metal chelation (Pietrangelo et al., 1995) free radical-scavenging (Winterbourn, 2008) and etc.,

The present study was carried out to investigate the protective effect of SB against arsenic induced oxidative stress, contents of lipids, proteins, antioxidant defense systems in various regions of rats. 


\section{Materials and methods}

\subsection{Chemicals}

Arsenic, silibinin, 1,1',3,3'-tetramethoxy propane and bovine serum albumin were purchased from Sigma Chemical Co., St. Louis, MO, USA. All other chemicals and solvents were of certified analytical grade and purchased from S.D. Fine Chemicals, Mumbai or Himedia Laboratories Pvt. Ltd., Mumbai, India. Reagent kits were obtained from span Diagnostics, Mumbai, India. Chemical structure of silibinin is shown in Fig. 1.

\subsection{Animals and diet}

Healthy adult male albino rats of Wistar strain, bred and reared in Central Animal House, Department of Experimental Medicine, Rajah Muthiah Medical College, Annamalai University were used for the experiment. Males were preferred in order to avoid complications of the oestrous cycle. Animals of equal weight (170-190 g) were selected and housed in polypropylene cages lined with husk and kept in a semi-natural light/dark condition (12 h light/12 h dark) The animals had free access to water and were supplied with standard pellet diet (Amrut Laboratory Animal Feed, Pranav Agro Industries Ltd., Bangalore, India), constitution of protein $(22.21 \%)$, fat $(3.32 \%)$, fibre $(3.11 \%)$, balanced with carbohydrates (> 67\%), vitamins and minerals. Animal handling and experimental procedures were approved by the Institutional Animal Ethics Committee, Annamalai University (Registration Number: 684/2010/CPCSEA) and the animals were cared in accordance with the "Guide for the care and use of laboratory animals" and "Committee for the purpose of control and supervision on experimental animals".

\subsection{Experimental design}

In the present study, $\mathrm{NaAsO}_{2}$ was administered orally at a dose of $5 \mathrm{mg} / \mathrm{kg}$ body weight/day for 4 weeks, which was $1 / 8$ of the ora $\mathrm{LD}_{50}$ values in rats (North et al., 1997). Control group received the vehicles only; experimental rats were subdivided into two groups (2 and 3). Drug control group received the SB (dissolved in $0.5 \%$ of carboxy methyl cellulose, CMC) alone. In the experiment, a total of 24 rats were used.The rats were randomly divided into 4 groups of 6 animals in each.

A pilot study was conducted with three different doses of SB (25, 50 and $75 \mathrm{mg} / \mathrm{kg}$ ) to determine the dose-dependenteffect of SB in as treated neurotoxic rats. After 4 weeks of experiment, it was observed that SB pretreatment at the doses of 25,50 and $75 \mathrm{mg} / \mathrm{kg}$ significantly $(\mathrm{p}<0.05)$ increased the levels of Acetylcholinesterase $(\mathrm{AChE})$ in plasma, reduced glutathione and lowered the thiobarbituric acid reactive substances in the brain of As intoxicated rats (data have not shown). $75 \mathrm{mg} / \mathrm{kg}$ of SB showed a higher significant effect than the lower doses 25 and $50 \mathrm{mg} / \mathrm{kg}$. Hence, we have chosen the highest dose $(75 \mathrm{mg} / \mathrm{kg})$ of $\mathrm{SB}$ as an effective dose against as toxicity for further studies.

Group 1: $(n=6)$ Considered as negative controls where rats received daily normal saline and CMC solutions used as vehicles.

Group 2: $(\mathrm{n}=6)$ Corresponding to As treated group where rats received daily $\mathrm{NaAsO}_{2}(5 \mathrm{mg} / \mathrm{kg} \mathrm{BW})$ dissolved in saline solution. Group 3: $(n=6)$ Rats received daily silibinin $(\mathrm{SB})$ dissolved in CMC (75 mg/kg BW) along with arsenic ( $5 \mathrm{mg} / \mathrm{kg} \mathrm{BW})$.

Group 4: $(n=6)$ Considered as positive controls where rats received daily SB dissolved in CMC (75 mg/kg BW).

The animals were maintained in their respective groups for four weeks. Food and fluid intake and body weights were measured weekly. At the end of the experimental period, the animals were anesthetized using ether and sacrificed by cervical decapitation. Blood was collected from the jugular vein using heparin as the anticoagulant and centrifuged at $2000 \mathrm{~g}$ for $20 \mathrm{~min}$ to prepare plasma. Brain tissues were excised washed and homogenized in $0.1 \mathrm{M}$ Tris-HCl-0.001M EDTA buffer (pH 7.4) and centrifuged at
$12,000 \times \mathrm{g}$ for $30 \mathrm{~min}$ at $4^{\circ} \mathrm{C}$. The supernatant was collected and used for the experiments.

\subsection{Determination of acetyl cholinesterase activity}

Acetylcholinesterase (AChE) activity was determined in plasma using acetylcholine iodide as a substrate according to the method of Ellman et al. (1961). In this method AChE in samples hydrolyzes acetylthiocholine iodide into thiocholine and butyric acid. The thiocholine reacts with 5,5'-dithiobis-2-nitrobenzoic acid to form 5- thio-2-nitrobenzoic acid. The yellow colour developed is measured spectrophotometrically at $412 \mathrm{~nm}$ (Elico-SL177, Elico LTD. Hyderabad Andra Pradesh, India).

\subsection{Dissection of the brain}

The brain was dissected into the cortex, striatum, cerebellum, hippocampus and the brain stem on a glass plate resting over crushed ice for separation of various regions (Glowinski and Iverson, 1966). The tissues were weighed to the nearest milligram on an electronic balance.

\subsection{Extraction of lipids from discrete brain areas}

Different parts of the brain, weighing between 150 to $300 \mathrm{mg}$ were homogenized in a glass homogenizer with a teflon pestle to a final volume of $6 \mathrm{ml}$ chloroform-methanol $(2: 1 \mathrm{v} / \mathrm{v})$ according to the method of Folch, et al. (1951), with a modified procedure. Homogenates were filtered under vacuum through a sintered glass funnel. The final volume of each extract was made up to $10 \mathrm{ml}$ with chloroform-methanol mixture. Thereafter, $2.5 \mathrm{ml}$ of normal saline solution was added to the extracts in each test tube $(4: 1$ $\mathrm{v} / \mathrm{v})$. This was shaken vigorously on a mixer and placed overnight at $-20^{\circ} \mathrm{C}$ in a deep freezer for separation of the two layers. Volumes of the upper and lower layers were marked respectively. The aqueous layer was used for the estimation of gangliosides and the lower layer was stored at $-20^{\circ} \mathrm{C}$ for the analysis of total lipids, phospholipids, cholesterol and cerebrosides. The analysis of total lipids was performed according to the method of Woodman and Price, (1972). Phospholipids were measured by phosphate determination according to the method of Marinetti, (1962). Cholesterol was estimated by Lieberman-Buchard reaction as described by Bloor, et al. (1922). Cerebrosides levels were determined by the method described for galactolipids and sulfolipids by Roughan and Batt, (1968). Gangliosides were determined according to the method of Pollet, et al. (1979). Protein was measured by the procedure of Lowry, et al. (1951).

\subsection{Estimation of brain ROS, LPO and PC}

ROS was measured as described previously, based on the oxidation of 2'71'-dichlorodihydrofluorescein diacetateto2'7'-dichlorofluorescein (Shinomol and Muralidhara, 2007). Briefly, the homogenate as diluted1:20 times with ice-cold Locke's buffer $(154 \mathrm{mMNaCl}, \quad 5.6 \mathrm{mMKCl}, \quad 3.6 \mathrm{mMNaHCO}, \quad 2.0 \mathrm{mMCaCl} 2$, $10 \mathrm{mM}$ d-glucose, and5mMHEPES, $\mathrm{pH} 7.4$ ) to obtain a concentration of $5 \mathrm{mgtissue} / \mathrm{ml}$. The reaction mixture $(1 \mathrm{ml})$ containing Locke's buffer (pH7.4), $0.2 \mathrm{ml}$ homogenate and $10 \mathrm{ml}$ of DCFH$\mathrm{DA}(5 \mathrm{mM})$ was incubated for $15 \mathrm{~min}$ at room temperature to allow the DCFH- DA to be incorporated into any membrane-bound vesicles and the diacetate group cleaved by esterases. After 30min of further incubation, the conversion of DCFH-DA to the fluorescent product DCF was measured using a spectrofluorimeter with excitation at $484 \mathrm{~nm}$ and emission at 530nm.Background fluorescence (conversion of DCFH-DA in the absence of homogenate) was corrected by the inclusion of parallel blanks. ROS formation was quantified from a DCF-standard curve and data are expressed as $\mathrm{pmol} \mathrm{DCF}$ formed/ $\mathrm{min} / \mathrm{mg}$ protein. 
Lipid peroxidation was assayed by the method of Ohkawa et al. (1979) in which the thiobarbituric acid reactive substance malondialdehyde released served as the index of LPO.

Protein carbonyl content was determined according to the method of Levine et al. (1990). Briefly $250 \mathrm{mg}$ mitochondrial protein was precipitated using $20 \%$ TCA followed by centrifugation at 10,000 $\mathrm{x} g$ for $10 \mathrm{~min}$ at $48 \mathrm{C}$. The supernatant obtained was discarded and the pellet was resuspendeddinitrophenylhydrazine $(10 \mathrm{mMin}$ $2 \mathrm{~N} \mathrm{HCl}$ ), kept at dark for an hour with occasional mixing. The tubes were then centrifuged at $10,000 \mathrm{x}$ g for $10 \mathrm{~min}$ at $48 \mathrm{C}$ and the pellet obtained was washed with acetone and dissolved in a known volume of Tris- $\mathrm{HCl}(20 \mathrm{mM}, \mathrm{pH} 7.4)$ containing $2 \%$ SDS. The absorbance was read at $360 \mathrm{~nm}$ and expressed as nmol carbonyls/mg protein (MEC-21.0 $\mathrm{mM}^{-1} 1 \mathrm{~cm}^{-1} 1$ ).

\subsection{Determination of non-enzymatic and enzymatic an- tioxidants}

Reduced glutathione was determined by the method of Ellman (1959). Total sulfhydryl groups were measured by the method of Ellman (1959). Vitamin C concentration was measured as previously reported (Omaye et al., 1979). Superoxide dismutase activity was determined by the method of Kakkar, et al. (1984). The activity of catalase was determined by the method of Sinha (1972). Glutathione peroxidase activity was estimated by the method of Rotruck, et al. (1973).Glutathione reductase was assayed by the method of Horn and Burns (1978). The estimation of glucose-6phosphate dehydrogenase was carried out by the method of Beutler (1983).

\subsection{Arsenic analysis}

Brain regional arsenic levels were estimated according to the method of Ballentine and Burford (1957).To $100 \mathrm{mg}$ of tissues, 1 $\mathrm{ml}$ of concentrated nitric acid was added, followed by $1 \mathrm{ml}$ of perchloric acid. The sample was then digested over a sand bath until the solution turned yellow in colour. If the colour of the digest was brown, more nitric acid and perchloric acid were added and the oxidation was repeated. The digest was made up to known volume with deionized water. Aliquots of this were used to estimate arsenic by using the atomic absorption spectrophotometer. The concentration of arsenic was expressed as $\mu \mathrm{g} / \mathrm{g}$ tissue.

\subsection{Histopathological studies}

For qualitative analysis of brain histology, the tissue samples were fixed for $48 \mathrm{~h}$ in $10 \%$ formalin-saline and dehydrated by passing successfully in different mixture of ethyl alcohol, water, cleaned in xylene and embedded in paraffin. Sections of the tissues (5$6 \mu \mathrm{m}$ thick) were prepared by using a rotary microtone and stained with haematoxylin and eosin dye, which was mounted in a neutral deparaffined xylene medium for microscopical observations. Six rats from each group were sacrificed for analyzing the hepatic histological examinations.

\subsection{Statistical analysis}

Data were analyzed by one way analysis of variance (ANOVA) followed by Duncan's multiple range test (DMRT) using a commercially available statistics software package (SPSS ${ }^{\circledR}$ for Windows, V. 17.0, Chicago, USA). Results were presented as mean \pm SD. Differences were considered significant if $\mathrm{P}<0.05$.

\section{Results}

\subsection{Effect of SB on body weight, organ weight, and rela- tive organ weight food and water intake}

Table 1 depicts the effects of as and SB on body weight gain, food and water intake and relative brain weight in control and experimental rats. In As treated rats, water and pellet diet consumption significantly $(\mathrm{p}<0.05)$ decreased with a decrease in body weight. A significant $(\mathrm{p}<0.05)$ decrease in relative brain weight was recorded in as treated rats when compared with control rats. Treatment with SB effectively attenuated the As-induced alterations in food and water intake, body weight and relative brain weight, when compared with as treated rats. Administration of SB alone to rats did not show any alterations in these parameters and did not differ significantly from that of the normal control group.

Table 1: Changes in Body Weight, Body Weight Gain, Food Intake, Water Intake and Organ-Body Weight Ratio in Control and Experimental Rats.

\begin{tabular}{|c|c|c|c|c|c|}
\hline \multicolumn{2}{|l|}{ Groups } & Control & Arsenic & $\begin{array}{l}\text { Arsenic } \\
+ \text { Silibin- } \\
\text { in }\end{array}$ & Silibinin \\
\hline \multirow{2}{*}{$\begin{array}{l}\text { Body } \\
\text { weight }\end{array}$} & Initial (g) & $\begin{array}{l}183.3 \pm \\
1.23\end{array}$ & $\begin{array}{l}189.5 \pm \\
7.2\end{array}$ & $\begin{array}{l}186.7 \pm \\
2.7\end{array}$ & $\begin{array}{l}180.0 \pm \\
2.4\end{array}$ \\
\hline & Final (g) & $\begin{array}{l}228.7 \pm \\
4.5\end{array}$ & $\begin{array}{l}172.5 \pm \\
3.9\end{array}$ & $\begin{array}{l}225.2 \pm \\
3.7\end{array}$ & $\begin{array}{l}233.8 \pm \\
5.3\end{array}$ \\
\hline \multicolumn{2}{|c|}{ Organ weight (g) brain } & $\begin{array}{l}1.72 \pm \\
0.03^{\mathrm{a}}\end{array}$ & $\begin{array}{l}1.59 \pm \\
0.02^{\mathrm{b}}\end{array}$ & $\begin{array}{l}1.67 \pm \\
0.03^{\mathrm{c}}\end{array}$ & $\begin{array}{l}1.70 \pm \\
0.04^{\mathrm{a}}\end{array}$ \\
\hline \multicolumn{2}{|c|}{$\begin{array}{l}\text { Food intake }(\mathrm{g} / 100 \mathrm{~g} \\
\text { bw/day) }\end{array}$} & $\begin{array}{l}14.08 \pm \\
0.83^{\mathrm{a}}\end{array}$ & $\begin{array}{l}9.15 \pm \\
0.57^{\mathrm{b}}\end{array}$ & $\begin{array}{l}12.39 \pm \\
0.71^{\mathrm{c}}\end{array}$ & $\begin{array}{l}13.86 \pm \\
0.93^{\mathrm{a}}\end{array}$ \\
\hline \multicolumn{2}{|c|}{$\begin{array}{l}\text { Water intake } \\
(\mathrm{mL} / \mathrm{rat} / \text { day })\end{array}$} & $\begin{array}{l}21.32 \pm \\
3.40^{\mathrm{a}}\end{array}$ & $\begin{array}{l}15.20 \pm \\
1.20^{\mathrm{b}}\end{array}$ & $\begin{array}{l}18.28 \pm \\
2.50^{\mathrm{c}}\end{array}$ & $\begin{array}{l}21.40 \pm \\
2.30^{\mathrm{a}}\end{array}$ \\
\hline \multicolumn{2}{|c|}{$\begin{array}{l}\text { Organ-body weight ratio } \\
(\%) \text { brain }\end{array}$} & $\begin{array}{l}0.82 \pm \\
0.007^{\mathrm{a}}\end{array}$ & $\begin{array}{l}0.59 \pm \\
0.004^{b}\end{array}$ & $\begin{array}{l}0.74 \pm \\
0.005^{\mathrm{c}}\end{array}$ & $\begin{array}{l}0.81 \pm \\
0.008^{\mathrm{a}}\end{array}$ \\
\hline
\end{tabular}

Values are expressed mean \pm SD for six rats in each group;

$\mathrm{a}, \mathrm{b}$ and $\mathrm{c} V$ alues are not sharing a common superscript letter (a-c) differ significantly at $\mathrm{p}<0.05$ (DMRT).

\subsection{Effect of SB on plasma AChE}

The activity of AChE in plasma of control and experimental rats is shown in Figure 1. The activities of AChE in plasma was significantly $(\mathrm{p}<0.05)$ decreased in as treated rats when compared with control rats, whereas the administration of SB in As intoxicated rats significantly $(\mathrm{p}<0.05)$ increased the activities of $\mathrm{AChE}$ to near normal levels when compared with As treated rats.

\subsection{Effect of SB on lipid profiles}

The effect of arsenic on the levels of total lipids (Figure 3), phospholipids (Figure 4), cholesterol (Figure 5), gangliosides(Figure 6) and cerebrosides(Figure 7) in various regions such as cortex, striatum, cerebellum, hippocampus and brain stem of the brain of control and arsenic treated rats. The significant $(\mathrm{p}<0.05)$ increased levels of total lipids, phospholipids, gangliosides and cerebrosides were observed in arsenic intoxicated rats when compared with control rats whereas the significant $(\mathrm{p}<0.05)$ decreased levels of cholesterol was observed in arsenic treated rats when compared with control rats. All lipid profiles levels were obtained near normal level in pre-administration of SB with As intoxicated rats when compared with As treated rats. There is no significant changes in SB alone treated rats when compared with control rats. 
<smiles>COc1cc(C2Oc3cc(C4Oc5cc(O)cc(O)c5C(=O)C(O)C4CO)ccc3OC2CO)ccc1O</smiles>

Fig. 1: Chemical Structure of Silibinin $\mathrm{C}_{25} \mathrm{H}_{22} \mathrm{O}_{10}$.

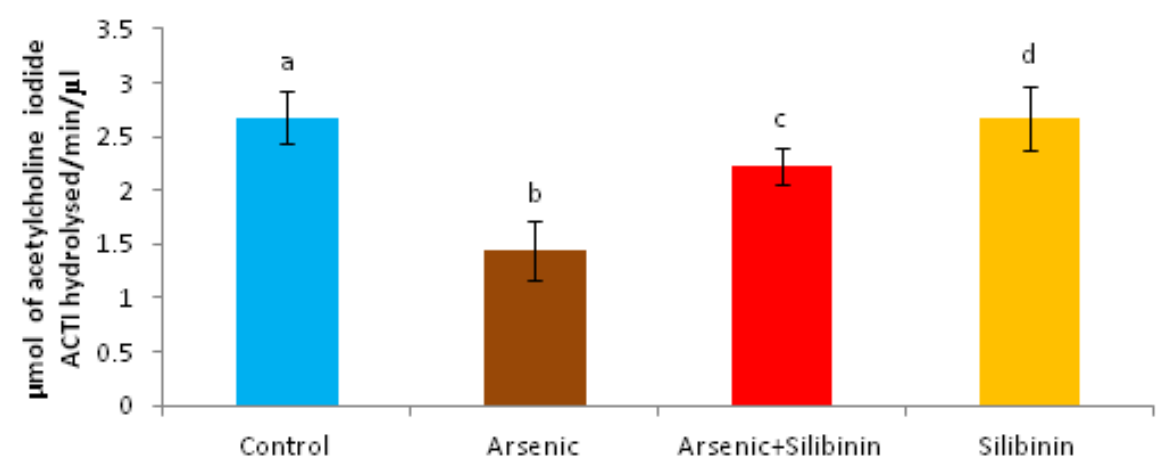

Fig. 2: Changes in the Activities of Acetylcholinesterase (Ache) in Plasma of Control and Experimental Rats. ATCI: Acetyl Thiocholine Iodide; Values are Mean \pm SD for Six Rats in Each Group. Values Not Sharing a Common Superscript Letters (a, b,c and d) Differ Significantly at P<0.05 (DMRT).

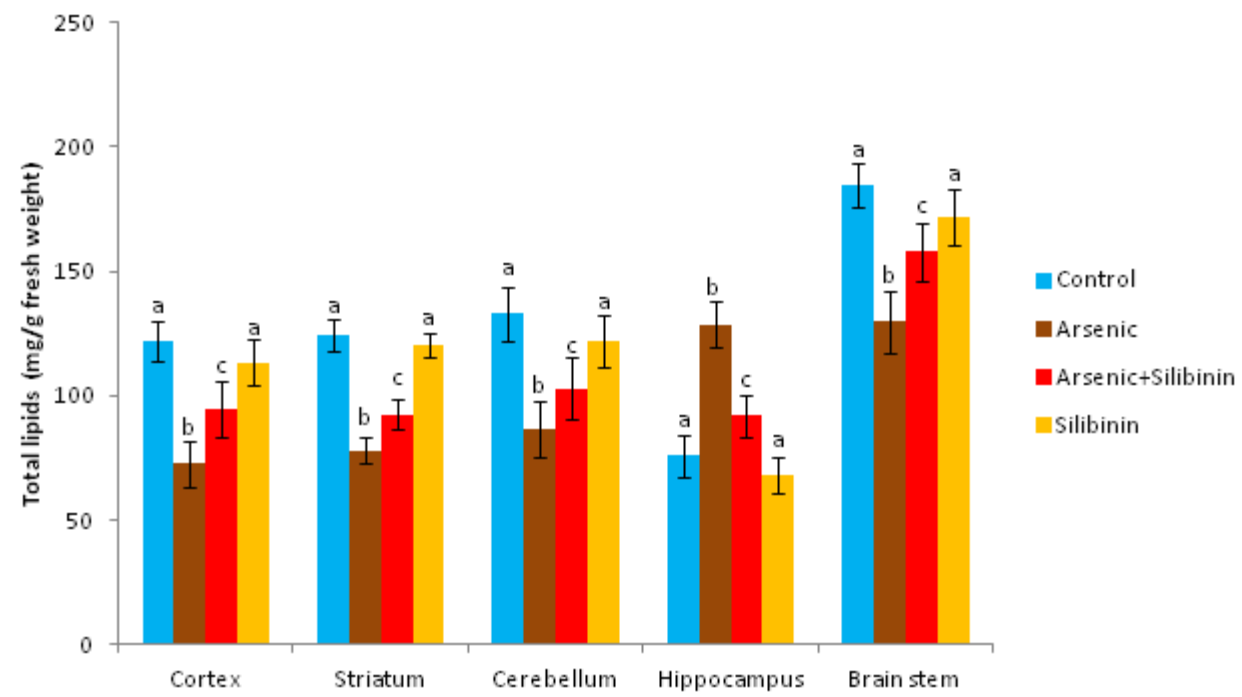

Fig. 3:Effect of Silibinin on the Levels of Total Lipids in Various Regions of Brain in the Control and Experimental Rats. Values are Mean \pm SD for 6 Rats in Each Group; ${ }^{\text {ab bandc }}$ Values are Not Sharing a Common Superscript Letter (a, b and c) Differ Significantly at P<0.05 (DMRT).

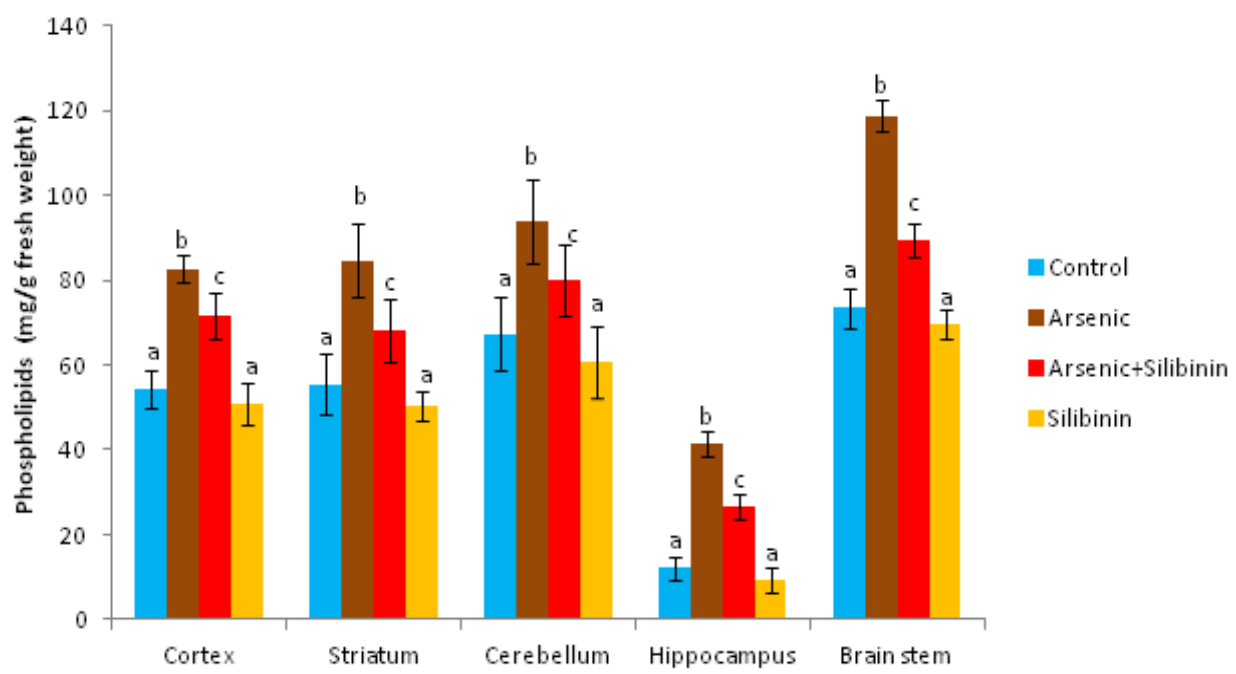

Fig. 4: Effect of Silibinin on the Levels of Phospholipids in Various Regions of Brain in the Control and Experimental Rats. Values are Mean \pm SD for 6 Rats in Each Group; ${ }^{\text {a, bandc }}$ Values are Not Sharing a Common Superscript Letter (a, b and c) Differ Significantly at P<0.05 (DMRT). 


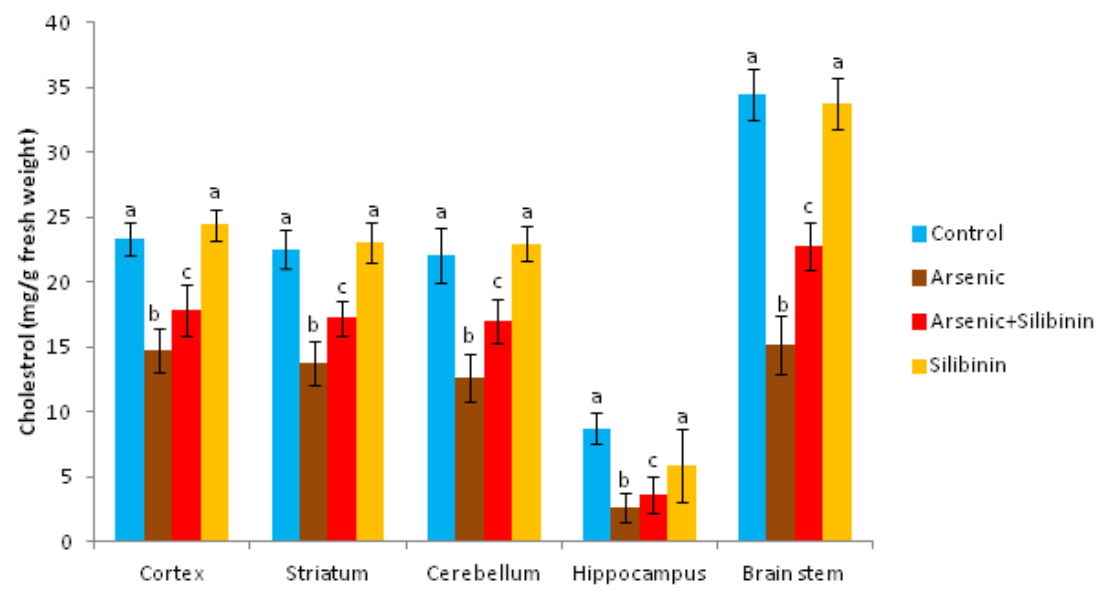

Figure 5

Fig. 5: Effect of Silibinin on the Levels of Cholestrol in Various Regions of Brain in the Control and Experimental Rats. Values are Mean \pm SD for 6 Rats in Each Group; ${ }^{\text {a, b and c }}$ Values are Not Sharing a Common Superscript Letter (a, b and c) Differ Significantly at P<0.05 (DMRT).

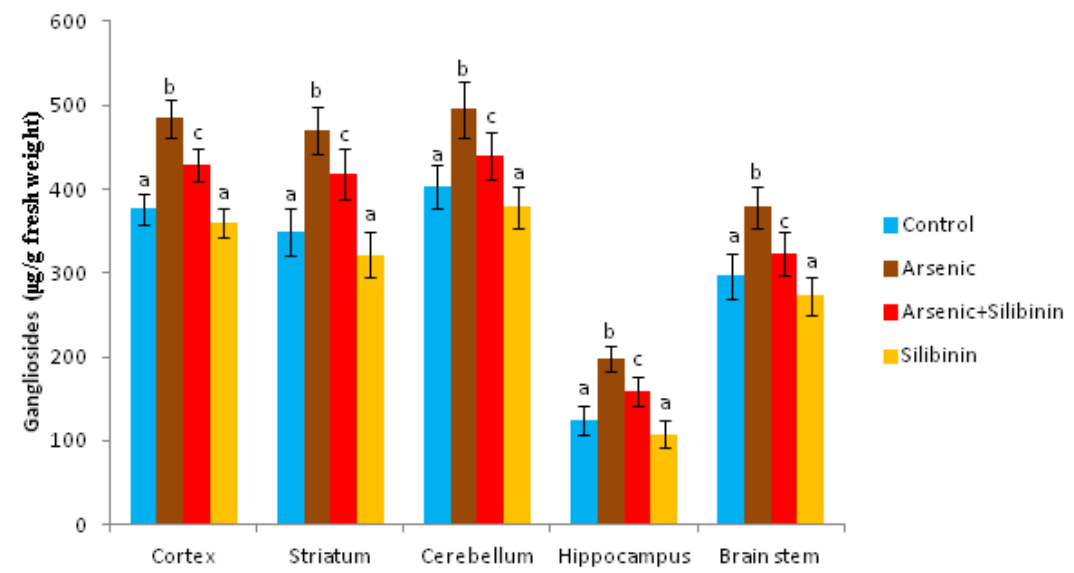

Figure 6

Fig. 6: Effect of Silibinin on the Levels of Gangliosides in Various Regions of Brain in the Control and Experimental Rats. Values are Mean \pm SD for 6 Rats in Each Group; ${ }^{a}$ band c Values are Not Sharing a Common Superscript Letter (a, b and c) Differ Significantly at P<0.05 (DMRT).

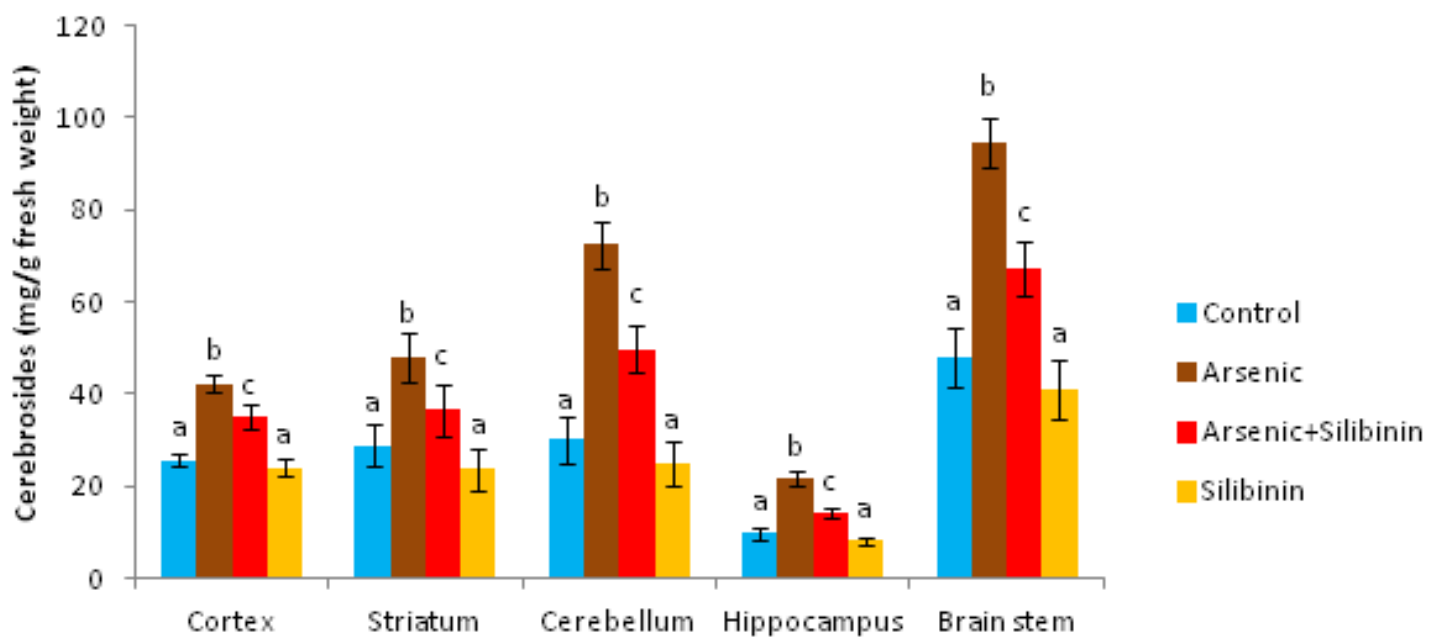

Fig. 7: Effect of Silibinin on the Levels of Cerebrosides in Various Regions of Brain in the Control and Experimental Rats. Values are Mean \pm SD for 6 Rats in Each Group; ${ }^{a, b}$ and c Values are Not Sharing a Common Superscript Letter (a, b and c) Differ Significantly at P<0.05 (DMRT).

\subsection{Effect of SB on ROS, lipid peroxidation and PC}

Table 2 illustrates the effect of silibinin on ROS, Lipid peroxidation and PC in cortex, striatum, cerebellum, hippocampus and brain stem of brain of control and arsenic treated rats. The levels of ROS, Lipid peroxidation and PC were significantly $(\mathrm{p}<0.05)$ increased in cortex, striatum, cerebellum, hippocampus and brain stem of arsenic treated rats when compared with control rats. The levels of ROS, Lipid peroxidation and PC were significantly 
$(\mathrm{p}<0.05)$ decreased in cortex, striatum, cerebellum, hippocampus and brain stem of pre-administration of SB when compared with As treated rats.

Table 2: Effect of Silibinin on the Levels of ROS, Lipid Peroxidation and $\mathrm{PC}$ in the Brain of Control and Experimental Rats.

\begin{tabular}{lccll} 
Groups & Control & Arsenic & $\begin{array}{l}\text { Arsenic }+ \\
\text { Silibinin }\end{array}$ & Silibinin \\
\hline ROS & & & & \\
Cortex & $1.65 \pm 0.48^{\mathrm{a}}$ & $3.48 \pm 0.25^{\mathrm{b}}$ & $2.04 \pm 0.53^{\mathrm{c}}$ & $1.43 \pm 0.27^{\mathrm{a}}$ \\
Striatum & $1.52 \pm 0.74^{\mathrm{a}}$ & $3.28 \pm 0.43^{\mathrm{b}}$ & $2.52 \pm 0.69 \mathrm{c}$ & $1.38 \pm 0.22^{\mathrm{a}}$ \\
Cerebellum & $1.24 \pm 0.65^{\mathrm{a}}$ & $2.78 \pm 0.48^{\mathrm{b}}$ & $1.98 \pm 0.53^{\mathrm{c}}$ & $1.08 \pm 0.21^{\mathrm{a}}$ \\
Hippocampus & $1.47 \pm 0.15^{\mathrm{a}}$ & $3.12 \pm 0.13^{\mathrm{b}}$ & $2.68 \pm 0.16^{\mathrm{c}}$ & $1.34 \pm 0.12^{\mathrm{a}}$ \\
Brain stem & $0.99 \pm 0.04^{\mathrm{a}}$ & $1.76 \pm 0.05^{\mathrm{b}}$ & $1.34 \pm 0.03^{\mathrm{c}}$ & $0.96 \pm 0.03^{\mathrm{a}}$ \\
Lipid peroxidation & & & \\
Cortex & $0.89 \pm 0.15^{\mathrm{a}}$ & $2.43 \pm 0.13^{\mathrm{b}}$ & $1.84 \pm 0.16^{\mathrm{c}}$ & $0.78 \pm 0.08^{\mathrm{a}}$ \\
Striatum & $0.74 \pm 0.12^{\mathrm{a}}$ & $1.98 \pm 0.14^{\mathrm{b}}$ & $1.18 \pm 0.15^{\mathrm{c}}$ & $0.60 \pm 0.14^{\mathrm{a}}$ \\
Cerebellum & $0.33 \pm 0.08^{\mathrm{a}}$ & $0.84 \pm 0.07^{\mathrm{b}}$ & $0.54 \pm 0.06^{\mathrm{c}}$ & $0.21 \pm 0.08^{\mathrm{a}}$ \\
Hippocampus & $0.58 \pm 0.05^{\mathrm{a}}$ & $1.48 \pm 0.08^{\mathrm{b}}$ & $0.98 \pm 0.07^{\mathrm{c}}$ & $0.47 \pm 0.07^{\mathrm{a}}$ \\
Brain stem & $0.28 \pm 0.05^{\mathrm{a}}$ & $0.72 \pm 0.07^{\mathrm{b}}$ & $0.43 \pm 0.06^{\mathrm{c}}$ & $0.22 \pm 0.05^{\mathrm{a}}$ \\
PC & & & & \\
Cortex & $3.87 \pm 0.24^{\mathrm{a}}$ & $5.88 \pm 0.18^{\mathrm{b}}$ & $4.43 \pm 0.17^{\mathrm{c}}$ & $3.62 \pm 0.23^{\mathrm{a}}$ \\
Striatum & $6.26 \pm 0.18^{\mathrm{a}}$ & $9.33 \pm 0.17^{\mathrm{b}}$ & $7.82 \pm 0.16^{\mathrm{c}}$ & $6.01 \pm 0.19^{\mathrm{a}}$ \\
Cerebellum & $2.75 \pm 0.12^{\mathrm{a}}$ & $5.78 \pm 0.14^{\mathrm{b}}$ & $3.85 \pm 0.13^{\mathrm{c}}$ & $2.58 \pm 0.15^{\mathrm{a}}$ \\
Hippocampus & $4.32 \pm 0.17^{\mathrm{a}}$ & $6.42 \pm 0.16^{\mathrm{b}}$ & $5.24 \pm 0.17^{\mathrm{c}}$ & $4.14 \pm 0.14^{\mathrm{a}}$ \\
Brain stem & $1.83 \pm 0.15^{\mathrm{a}}$ & $4.57 \pm 0.13^{\mathrm{b}}$ & $2.76 \pm 0.14^{\mathrm{c}}$ & $1.67 \pm 0.12^{\mathrm{a}}$ \\
\hline
\end{tabular}

Values are mean \pm SD for 6 rats in each group; ${ }^{\text {a b, c and d }}$ Values are not sharing a common superscript letter

(a-d) differ significantly at $\mathrm{p}<0.05$ (DMRT).

The levels of ROS were expressed as pmol DCF/min/mg protein.

The levels of lipid peroxidation were expressed as $\mu \mathrm{mol} \mathrm{H}_{2} \mathrm{O}_{2} / \mathrm{mg}$ protein. The levels of PC were expressed as $\mathrm{nmol} / \mathrm{mg}$ protein.

\subsection{Effect of SB on non-enzymatic antioxidants}

The effect of SB on GSH, TSH and vitamin C in cortex, striatum, cerebellum, hippocampus and brain stem of brain of control and arsenic treated rats illustrated in figure 8, figure 9 and figure 10 . The levels of non-enzymatic antioxidants were significantly $(p<0.05)$ decreased in cortex, striatum, cerebellum, hippocampus and brain stem of arsenic treated rats when compared with control rats. Pre administration of SB significantly $(\mathrm{p}<0.05)$ increased the levels of non-enzymatic antioxidants in as treated rats when compared with as alone treated rats. The levels of non-enzymatic antioxidants also similar like that of control rats.

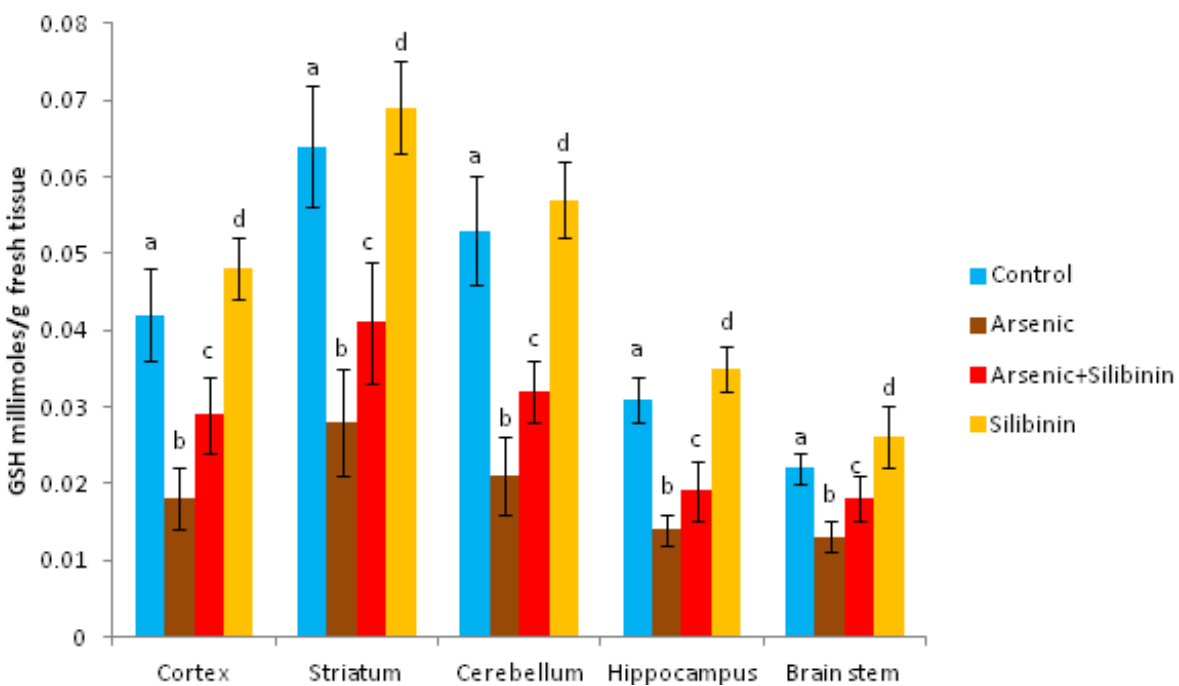

Fig. 8: Effect of Silibinin on the Levels of GSH in Various Regions of Brain in the Control and Experimental Rats. Values are Mean \pm SD for 6 Rats in Each Group; ${ }^{\text {A,B, Cand }}$ values are Not Sharing a Common Superscript Letter (A, B and C) Differ Significantly at $\mathrm{P}<0.05$ (DMRT).

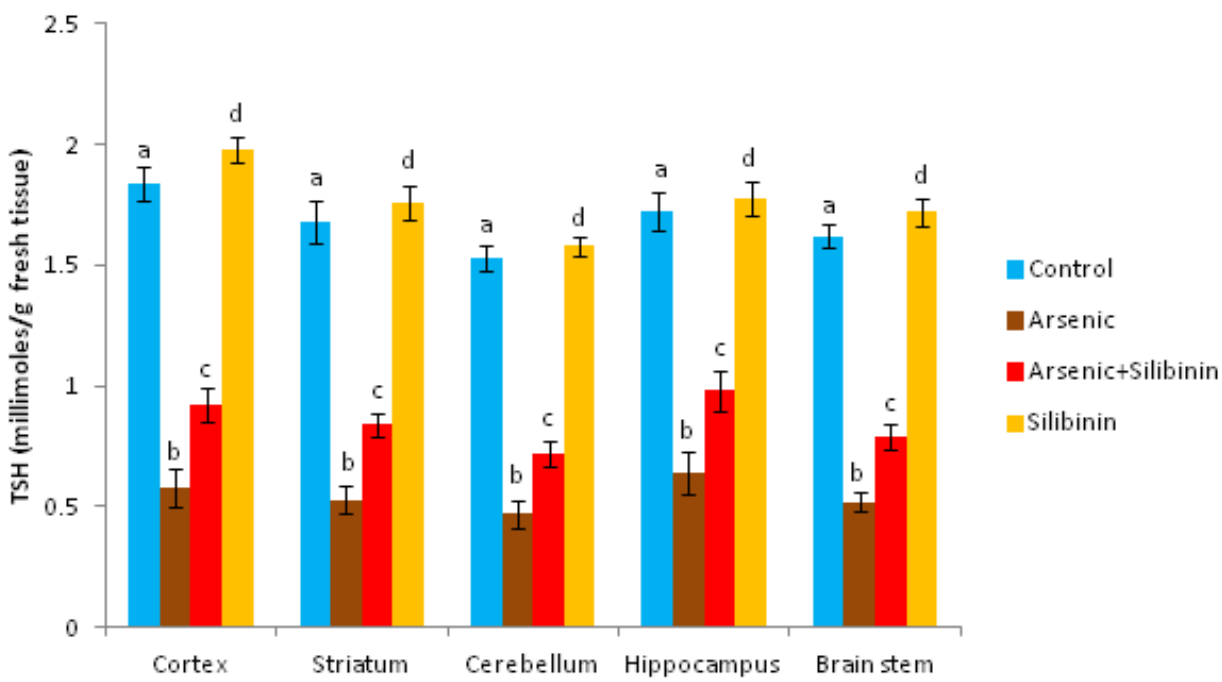

Fig. 9: Effect of Silibinin on the Levels of TSH in Various Regions of Brain in the Control and Experimental Rats. Values are Mean \pm SD for 6 Rats in Each Group; ${ }^{\text {ab, candd }}$ values are Not Sharing a Common Superscript Letter (a, b, c and d) Differ Significantly at $\mathrm{P}<0.05$ (DMRT). 


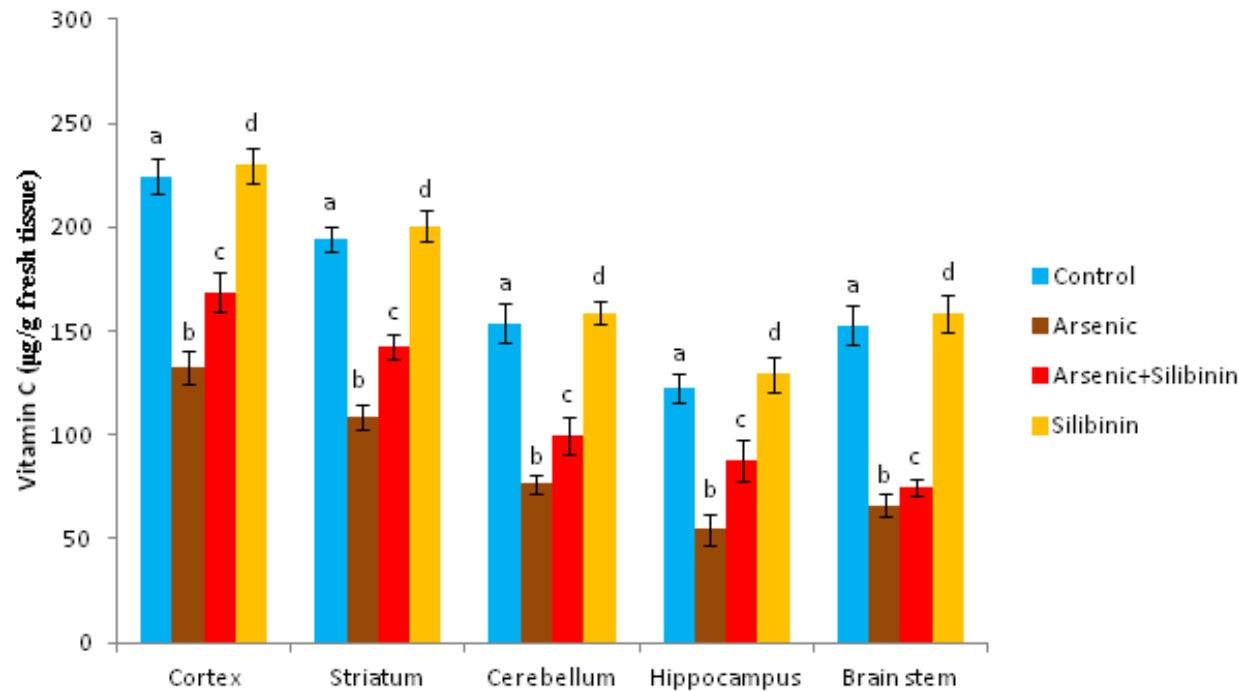

Fig. 10: Effect of Silibinin on the Levels of Vitamin "C" in Various Regions of Brain in the Control and Experimental Rats. Values are Mean \pm SD for 6 Rats in Each Group; ${ }^{\text {a b, cand d }}$ values are Not Sharing a Common Superscript Letter (a, b, c and d) Differ Significantly at P<0.05 (DMRT).

\subsection{Effect of SB on enzymatic antioxidants}

The activities of enzymatic antioxidants such as SOD, CAT, $\mathrm{GP}_{\mathrm{X}}$ GST, GR and G6PD in cortex, striatum, cerebellum, hippocampus and brain stem were illustrated in the table 3 and table 4 . Arsenic treated rats significantly $(\mathrm{p}<0.05)$ reduced the activities of enzymatic antioxidants when compared with control rats whereas the pre-administration of SB in as treated rats significantly $(p<0.05)$ increased the activities of enzymatic antioxidants when compared with arsenic alone treated rats. The activities of enzymatic antioxidants also similar like that of control rats.

Table 3: Effect of Silibinin on the Activities of SOD, CAT and Gpx in the Brain of Control and Experimental Rats

\begin{tabular}{lllll}
\multicolumn{5}{c}{ in the Brain of Control and Experimental Rats } \\
\hline Groups & Control & Arsenic & $\begin{array}{l}\text { Arsenic }+ \\
\text { Silibinin }\end{array}$ & Silibinin \\
\hline SOD & & & & \\
Cortex & $5.32 \pm 0.28^{\mathrm{a}}$ & $3.41 \pm 0.24^{\mathrm{b}}$ & $4.02 \pm 0.32^{\mathrm{c}}$ & $5.48 \pm 0.26^{\mathrm{d}}$ \\
Striatum & $4.98 \pm 0.20^{\mathrm{a}}$ & $2.78 \pm 0.25^{\mathrm{b}}$ & $3.54 \pm 0.24^{\mathrm{c}}$ & $5.01 \pm 0.22^{\mathrm{d}}$ \\
Cerebellum & $5.22 \pm 0.16^{\mathrm{a}}$ & $3.24 \pm 0.14^{\mathrm{b}}$ & $4.04 \pm 0.19^{\mathrm{c}}$ & $5.38 \pm 0.18^{\mathrm{d}}$ \\
& & & & \\
Hippocampus & $4.64 \pm 0.12^{\mathrm{a}}$ & $2.63 \pm 0.14^{\mathrm{b}}$ & $3.04 \pm 0.15^{\mathrm{c}}$ & $4.85 \pm 0.12^{\mathrm{d}}$ \\
& & & & \\
Brain stem & $4.22 \pm 0.15^{\mathrm{a}}$ & $2.13 \pm 0.18^{\mathrm{b}}$ & $3.32 \pm 0.15^{\mathrm{c}}$ & $4.43 \pm 0.17^{\mathrm{d}}$ \\
CAT & & & & \\
Cortex & $6.42 \pm 0.38^{\mathrm{a}}$ & $3.21 \pm 0.34^{\mathrm{b}}$ & $4.73 \pm 0.33^{\mathrm{c}}$ & $6.61 \pm 0.35^{\mathrm{d}}$ \\
Striatum & $4.34 \pm 0.24^{\mathrm{a}}$ & $2.12 \pm 0.34^{\mathrm{b}}$ & $3.18 \pm 0.23^{\mathrm{c}}$ & $4.51 \pm 0.38^{\mathrm{d}}$ \\
Cerebellum & $2.98 \pm 0.16^{\mathrm{a}}$ & $1.01 \pm 0.17^{\mathrm{b}}$ & $1.92 \pm 0.18^{\mathrm{c}}$ & $3.24 \pm 0.17^{\mathrm{d}}$ \\
Hippocampus & $8.02 \pm 0.44^{\mathrm{a}}$ & $4.48 \pm 0.48^{\mathrm{b}}$ & $6.12 \pm 0.52^{\mathrm{c}}$ & $8.23 \pm 0.49^{\mathrm{d}}$ \\
Brain stem & $1.14 \pm 0.09^{\mathrm{a}}$ & $0.58 \pm 0.08^{\mathrm{b}}$ & $0.82 \pm 0.07^{\mathrm{c}}$ & $1.32 \pm 0.08^{\mathrm{d}}$ \\
GPx & & & & \\
Cortex & $2.78 \pm 0.23^{\mathrm{a}}$ & $1.82 \pm 0.18^{\mathrm{b}}$ & $2.38 \pm 0.21^{\mathrm{c}}$ & $2.96 \pm 0.24^{\mathrm{d}}$ \\
Striatum & $3.84 \pm 0.18^{\mathrm{a}}$ & $2.58 \pm 0.21^{\mathrm{b}}$ & $3.12 \pm 0.19^{\mathrm{c}}$ & $4.08 \pm 0.21^{\mathrm{d}}$ \\
Cerebellum & $1.98 \pm 0.14^{\mathrm{a}}$ & $1.12 \pm 0.16^{\mathrm{b}}$ & $1.53 \pm 0.17^{\mathrm{c}}$ & $2.18 \pm 0.14^{\mathrm{d}}$ \\
Hippocampus & $1.84 \pm 0.16^{\mathrm{a}}$ & $1.03 \pm 0.14^{\mathrm{b}}$ & $1.42 \pm 0.15^{\mathrm{c}}$ & $2.07 \pm 0.16^{\mathrm{d}}$ \\
Brain stem & $1.89 \pm 0.15^{\mathrm{a}}$ & $1.14 \pm 0.16^{\mathrm{b}}$ & $1.48 \pm 0.15^{\mathrm{c}}$ & $2.03 \pm 0.17^{\mathrm{d}}$ \\
\hline Var
\end{tabular}

Values are mean \pm SD for 6 rats in each group; ${ }^{\text {a, b, cand d }}$ Values are not sharing a common superscript letter (a-d) differ significantly at $\mathrm{p}<0.05$ (DMRT)

SOD - One unit of enzyme activity was taken as the enzyme reaction, which gave $50 \%$ inhibition of NBT reduction in one minute/mg protein.

CAT $-\mu \mathrm{mol}$ of $\mathrm{H}_{2} \mathrm{O}_{2}$ utilized $/ \mathrm{min} / \mathrm{mg}$ protein. GPx- $\mu \mathrm{g}$ of GSH consumed $/ \mathrm{min} / \mathrm{mg}$ protein.

Table 4: Effect of Silibinin on the Activities of GST, GR and G6PD in the Brain of Control and Experimental Rats

\begin{tabular}{lllll}
\hline Groups & Control & Arsenic & $\begin{array}{l}\text { Arsenic }+ \\
\text { Silibinin }\end{array}$ & Silibinin \\
\hline GST & & & & \\
Cortex & $2.41 \pm 0.14^{\mathrm{a}}$ & $1.73 \pm 0.13^{\mathrm{b}}$ & $2.02 \pm 0.18^{\mathrm{c}}$ & $2.63 \pm 0.16^{\mathrm{d}}$ \\
Striatum & $1.86 \pm 0.08^{\mathrm{a}}$ & $0.97 \pm 0.07^{\mathrm{b}}$ & $1.39 \pm 0.06^{\mathrm{c}}$ & $2.04 \pm 0.09^{\mathrm{d}}$ \\
\hline
\end{tabular}

\begin{tabular}{lcccc}
\hline Cerebellum & $1.73 \pm 0.05^{\mathrm{a}}$ & $1.02 \pm 0.08^{\mathrm{b}}$ & $1.36 \pm 0.06^{\mathrm{c}}$ & $1.97 \pm 0.04^{\mathrm{d}}$ \\
Hippocampus & $2.68 \pm 0.08^{\mathrm{a}}$ & $1.84 \pm 0.05^{\mathrm{b}}$ & $2.24 \pm 0.06^{\mathrm{c}}$ & $2.78 \pm 0.05^{\mathrm{d}}$ \\
Brain stem & $1.24 \pm 0.04^{\mathrm{a}}$ & $0.76 \pm 0.05^{\mathrm{b}}$ & $0.98 \pm 0.08^{\mathrm{c}}$ & $1.36 \pm 0.04^{\mathrm{d}}$ \\
& & & & \\
Cortex & $0.65 \pm 0.12^{\mathrm{a}}$ & $0.38 \pm 0.13^{\mathrm{b}}$ & $0.49 \pm 0.12^{\mathrm{c}}$ & $0.71 \pm 0.11^{\mathrm{d}}$ \\
Striatum & $0.58 \pm 0.09^{\mathrm{a}}$ & $0.27 \pm 0.12^{\mathrm{b}}$ & $0.41 \pm 0.11^{\mathrm{c}}$ & $0.64 \pm 0.12^{\mathrm{d}}$ \\
Cerebellum & $0.33 \pm 0.06^{\mathrm{a}}$ & $0.16 \pm 0.07^{\mathrm{b}}$ & $0.27 \pm 0.06^{\mathrm{c}}$ & $0.42 \pm 0.05^{\mathrm{d}}$ \\
$\begin{array}{l}\text { Hippocampus } \\
\text { Brain stem }\end{array}$ & $0.19 \pm 0.02^{\mathrm{a}}$ & $0.08 \pm 0.03^{\mathrm{b}}$ & $0.14 \pm 0.03^{\mathrm{c}}$ & $0.25 \pm 0.04^{\mathrm{d}}$ \\
$\begin{array}{l}\text { G6PD } \\
\text { Cortex }\end{array}$ & $0.28 \pm 0.07^{\mathrm{a}}$ & $0.16 \pm 0.08^{\mathrm{b}}$ & $0.21 \pm 0.06^{\mathrm{c}}$ & $0.34 \pm 0.07^{\mathrm{d}}$ \\
& $1.48 \pm 0.24^{\mathrm{a}}$ & $0.82 \pm 0.18^{\mathrm{b}}$ & $1.12 \pm 0.16^{\mathrm{c}}$ & $1.62 \pm 0.23^{\mathrm{d}}$ \\
Striatum & $1.32 \pm 0.18^{\mathrm{a}}$ & $0.65 \pm 0.16^{\mathrm{b}}$ & $0.98 \pm 0.17^{\mathrm{c}}$ & $1.38 \pm 0.18^{\mathrm{d}}$ \\
& & & \\
Cerebellum & $0.92 \pm 0.14^{\mathrm{a}}$ & $0.58 \pm 0.12^{\mathrm{b}}$ & $0.69 \pm 0.13^{\mathrm{c}}$ & $0.99 \pm 0.12^{\mathrm{d}}$ \\
Hippocampus & $0.73 \pm 0.08^{\mathrm{a}}$ & $0.43 \pm 0.09^{\mathrm{b}}$ & $0.58 \pm 0.08^{\mathrm{c}}$ & $0.78 \pm 0.09^{\mathrm{d}}$ \\
& & & \\
Brain stem & $0.83 \pm 0.06^{\mathrm{a}}$ & $0.38 \pm 0.05^{\mathrm{b}}$ & $0.49 \pm 0.06^{\mathrm{c}}$ & $0.89 \pm 0.05^{\mathrm{d}}$ \\
\hline
\end{tabular}

\subsection{Effect of SB on arsenic concentration}

Figure 11 shows the concentration of as in cortex, striatum, cerebellum, hippocampus and brain stem of control and as treated rats. Accumulation of as significantly $(\mathrm{p}<0.05)$ increased in various regions of brain such as cortex, striatum, cerebellum, hippocampus and brain stem when compared with control rats. The preadministration of SB significantly $(\mathrm{p}<0.05)$ reduced the accumulation of as in arsenic treated rats when compared with as alone treated rats. There is no significant $(\mathrm{p}<0.05)$ changes in the accumulation of As in SB alone rats when compared with control rats.

\subsection{Histopathological changes in brain}

Figure 12 illustrate the histopathological assessment of brain tissue of control and experimental animals. Arsenic intoxicatedrats exhibited marked gliosis, nuclear pycnosis, spongiform necrosis and lymphocytic inflammatory infiltrates (Figure 12B and Figure 12C) as against normal architecture shown by the brain of vehicle (Figure 12A) and silibinin control rats (Figure 12E). Treatment with silibinin prior to the arsenic intoxication (Figure 12D) reduced the incidence of these pathological changes in the brain tissue and showed almost normal architecture similar to that of the untreated control. 


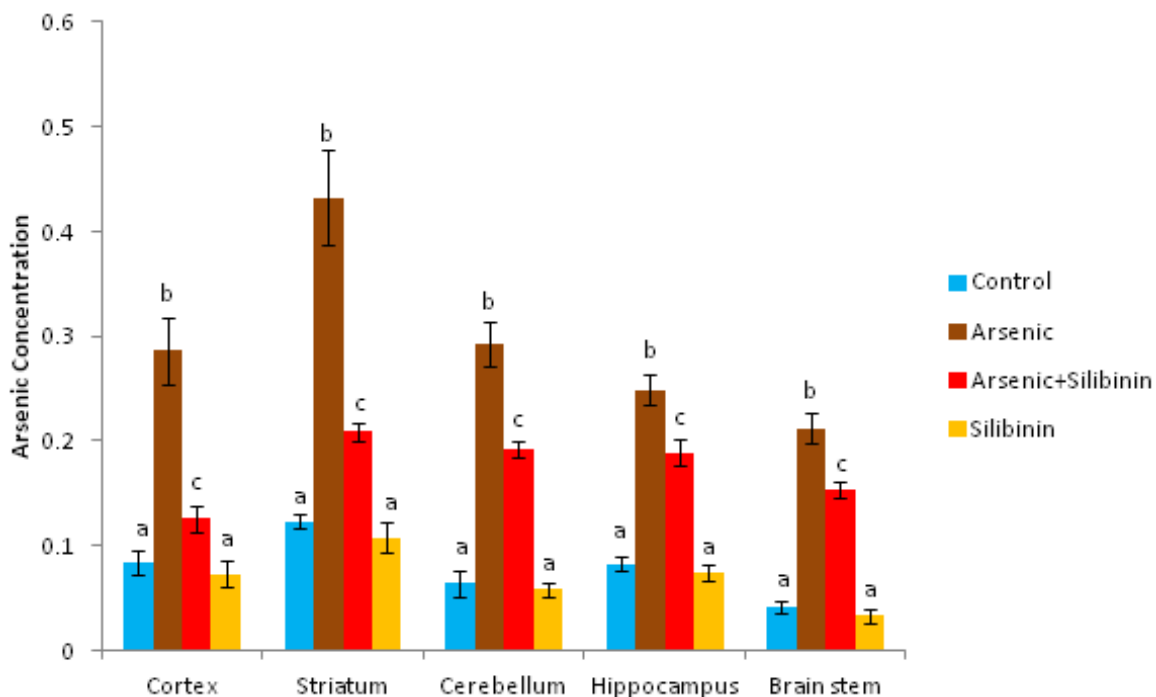

Fig. 11:Effect of Silibinin on the Concentration of as in Various Regions of B rain in the Control and Experimental Rats. Values are Mean \pm SD for 6 Rats in Each Group; ${ }^{\text {a, band c }}$ Values are Not Sharing a Common Superscript Letter (a, b and c) Differ Significantly at P<0.05 (DMRT).
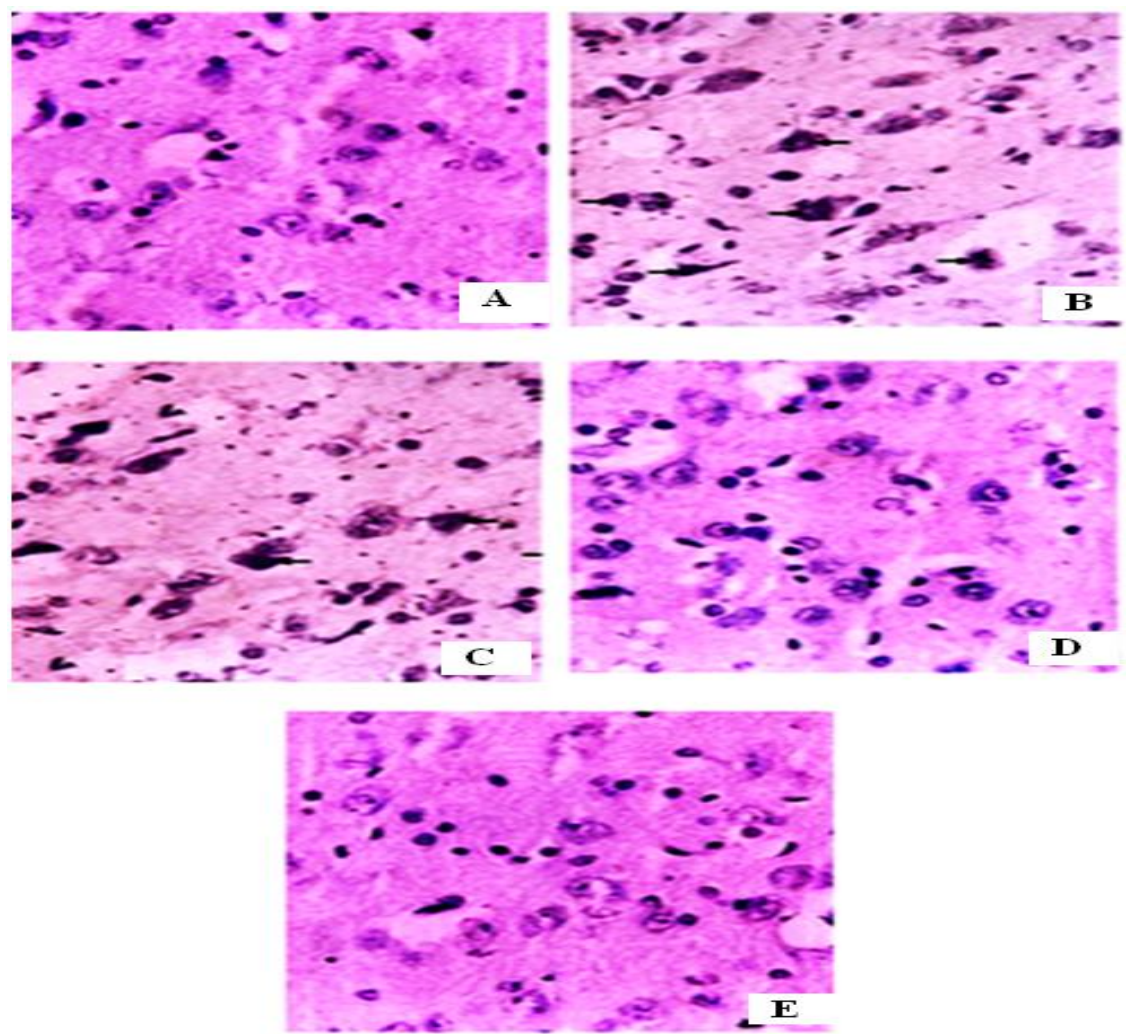

Fig. 12: Representative Photomicrographs Showing Histopathological Changes in Rat Brain (H \& E, X400) of Control and Experimental Rats. (A) Control Rat Brain Showing the Normal Histological Architecture (H \& E, X400). (B and C) Arsenic Intoxicated Rats Showing the Cerebral Cortex with Predominantly Shrinkage, Pyknotic, Necrosedand Deeply-Stained Neurons (Arrows) (H \& E, X400). (D) Arsenic and Silibinin Treated Rats Showing the Cerebral Cortex with Normal Appearance of the Majority of Neurons (H \& E, X400). (E) Silibinin Treated Rats Showing Normal Histology of Brain (H \& $\mathrm{E}, 400)$.

\section{Discussion}

The present study evaluated the effects of silibinin on arsenicinduced oxidative stress in rat brain. The central nervous system may be one of the important target sites for arsenic to exert its toxicological effects (Sinha et al., 2008a).At the same time, the brain compared to lung, liver and other organs, contains relatively low levels of enzymatic and non-enzymatic antioxidants and high amounts of peroxidizable unsaturated lipids, rendering it more vulnerable to oxidative stress compared to other tissue (Bondy, 1997). Increasing evidences suggested that, excessive production free radicals in brain and the imbalance between oxidative species and antioxidant defenses are related to the pathogenesis of neurodegenerative diseases (Halliwell, 2006).

$\mathrm{AChE}$ is one of the most essential enzymes needed for the proper functioning of the nervous system and muscle contraction in brain. The inhibition of AChE activity in as toxicity due to the free radical generation and oxidative stress induced ill effects were already reported by Bharti et al., (2012). The data obtained from this study clearly show that as significantly decreased the activity of AChE in plasma of rats. In the present study pre administration of SB in as intoxicated rats significantly elevated the activity of AChE due to its neuroprotective effect (Wang et al., 2002).

Arsenic induced ROS play a notable damage in regional brain lipid profiles (Haiderand Najar, 2008). Furthermore in the present investigation As intoxicated rats significantly decreased the total lipids and cholesterol in cortex, striatum, cerebellum, hippocam- 
pus and brain stem whereas As also increased the Phospholipids, Gangliosides and Cerebrosides. Our results remarkably correlated with the earlier finding of Haiderand Najar, (2008). Preadministration of SB modulates the As induced oxidative damage in regional brain lipid profiles. This could be due to the ability of silibinin to protect the $\mathrm{SH}$ groups from the oxidative damage through the inhibition of peroxidation of lipids and stabilizes the membrane. In addition SB has a potential protective role in the impairment of lipid profiles (Mccarty, 2005).

Normally the brain has moderately poor antioxidant defense (Mates, 2000) and it contains large amounts of polyunsaturated fatty acids and consumes $20 \%$ of the body's oxygen (Travacio et al., 2000). In the present study, arsenic intoxication induced a high degree of ROS production, lipid peroxidation and also protein damage like increased PC content in the various region of brain tissue of the experimental rats due to the susceptibility of the brain tissue toward oxidative damage. The presence of ROS in various regions of brain in the following conditions: Cortex $>$ Striatum $>$ Hippocampus $>$ Cerebellum $>$ Brainstem likewise in lipid peroxidation. As induced protein damage was in the following order: Striatum > Hippocampus $>$ Cortex $>$ Cerebellum $>$ Brainstem. Treatment with SB prior to arsenic administration significantly decreased the extent of ROS, lipid peroxidation and protein carbonyl contents. SB probably suppresses lipid peroxidation and protein carbonyl contents through different chemical mechanisms, including free radical quenching, electron transfer, radical addition, or radical recombination due to its three hydroxyl groups at $3^{\text {rd }}, 5^{\text {th }}$ and $7^{\text {th }}$ positions (Rajnarayana et al., 2001; Basiglio et al., 2009). Interestingly, the suppression of lipid peroxidation also interrelated with the impairment of regional brain lipid profiles to near normal levels.

Antioxidant enzymes are considered to be the first line of cellular defense against oxidative damage. SOD is an antioxidant metallo enzyme that reduces superoxide radicals to water and molecular oxygen (McCord et al., 1976). CAT is a haemoprotein, which reduces hydrogen peroxide to molecular oxygen and water (Gutteridge, 1995). Reduction in SOD activity in brain tissue of arsenic-exposed animals may be due to the enhanced production of super oxide radical anions (Yamanaka et al., 1991). Arsenic intoxication also significantly reduced the CAT activity in the brains of experimental rats. NADH is required for the activation of CAT from its inactive form. The paucity of NADH accumulation during arsenic metabolism might decrease the catalase activity (Kirkman and Gaetani, 1984). GST and GPx two antioxidant enzymes, which counteract free radical generation. GST and GPx play principle roles in the reduction of organic hydroperoxides within membranes and lipoproteins in the presence of GSH. Decrease in GSH content and increase in the level of lipid peroxidation due to arsenic toxicity simultaneously decreased the activities of GST and GPx with a concomitant decrease in the activity of GSHregenerating enzyme, glutathione reductase (GR). G6PD is an important enzyme of hexosemonophosphate (HMP) shunt. It converts one molecule of glucose-6-phosphate into 6- phosphogluconolactone in the presence of $\mathrm{Mg}^{2+}, \mathrm{Mn}^{2+}$ and $\mathrm{Ca}^{2+}$ ions and subsequently $\mathrm{NADP}^{+}$is reduced to NADPH. A subsequent reduction of the G6PD activity in arsenic-induced rats showed impaired generation of NADPH, which is required for the reduction of GSSG to GSH (Hughes, 2002; Shila et al., 2005). SB treatment prior to arsenic intoxication prevented the alterations in the activities of SOD, CAT, GST, GPx, GR and G6PD in brain probably due to the free-radicalscavenging properties via carbonyl oxygen and $\mathrm{OH}$ groups $(3-\mathrm{OH}$ or $5-\mathrm{OH})$ to form the metal-oxygen bonds in the complexes (Naso et al., 2011) and also confer higher stability to the radical form and to participate in electron donating to the free radicals.

Non-enzymatic antioxidants contribute another line of cellular defense against arsenic-induced oxidative damage. GSH functions as a catalyst in disulfide exchange reaction. It functions by scavenging free radicals as well as by detoxifying various xenobiotics and is consequently converted to glutathione disulfide (GSSG) (Jones, 2002). Treatment with SB prior to the arsenic administra- tion could prevent the As-induced alteration of non-enzymatic antioxidant markers such as GSH, TSH and Vit "C" probably due to its free radical scavenging activity (Basiglio et al., 2009).

More over in the present study, the accumulation of as in the various regions of brain tissue significantly reduced by the preadministration of SB in as intoxicated rats. The accumulation of as in regional brain tissues occurs in the following order: Striatum > Hippocampus > Cortex > Cerebellum > Brainstem. In our study, $\mathrm{SB}$ increases the GSH levels in various regions of brain it may decreases the As content due to oxidation of GSH by free radicals (Manna et al., 2008; Afzal et al., 2002) or sulfhydryl group of cysteine moiety in GSH has a high affinity for As forming AsGSH complex or its electron donor ability and finally these complexes excreted via the bile (Radabaugh and Aposhian, 2000).

Histopathological observation of the brain tissue reveals that arsenic intoxication caused abnormal ultra-structural changes in the brain tissue, including spongiform necrosis, nuclear vacuolization, pycnosis and lymphocytic inflammatory changes. Regarding the histopathological observation, no significant difference has been observed between control, and silibinin treated groups. Silibinin pretreated arsenic intoxicated rats the observed pathological impairments by arsenic have been recovered significantly, which indicate the neuroprotective efficacy of silibinin is capable of preventing the neuronal damage and oxidative stress induced by arsenic.

From the present study, as induced ROS produced severe neurotoxic and dyslipidemia in various regions of rats. SB primarily prevents the As induced ROS due to its free-radical scavenging efficacy of trihydroxyl groups (C-3, C-5 and C-7) in the A and B ring and one methoxy group (C-3') in the $\mathrm{C}$ ring of SB. SB neutralizes the ROS due to its hydroxyl and methoxy groups, by the way, of donating $\mathrm{H}$-atom to the unpaired electrons. In addition, the presence of $\mathrm{C}=\mathrm{O}$ in the $\mathrm{B}$ ring also facilitates the dismutation of as induced ROS. Interestingly, the free-radical scavenging efficacy by SB also enhances the enzymatic and non-enzymatic antioxidant status. Moreover, the prevention of lipid peroxidation by SB helps to restore the altered lipid profiles by as in the various regions of experimental rats.

\section{Conclusion}

From the observations, we conclude that SB has protective effects on as induced oxidative neurotoxicity in rats. The underlying mechanism is likely that SB prevents oxidative damage by scavenging free radicals generated during As metabolism thus inhibiting the peroxidation of membrane lipids and preventing subsequent leakage of soluble enzymes,facilitates the rejuvenation of antioxidant status and normal histological architecture of brain tissue. The natural polyphenolic antioxidant like SB has excellent scope to counteract as induced oxidative stress mediated neurotoxicity and dyslipidemia in exposed subjects via their occupational and environmental settings.

Conflicts of interest statement

The authors declare that there are no conflicts of interest.

\section{Acknowledgement}

Authors extend their thanks to the Professor and Head, Department of Zoology and UGC-SAP (DRS-I) for their generous support in this study.

\section{References}

[1] Afzal M, Afzal A, Jones A, Armstrong D (2002), A rapid method for the quantification of GSH and GSSG in biological samples. In: Armstrong D, editor. Oxidative stress biomarkers and antioxidant protocol. Humana Press 117-22.http://dx.doi.org/10.1385/1-59259173-6:117. 
[2] Ballentine R, Burford DD (1957), Determination of metals. Methods Enzymol 3:1002-1035http://dx.doi.org/10.1016/S00766879(57)03493-X.

[3] Basiglio CL, Sanchez Pozzi EJ, Mottino AD, Roma MG(2009) Differential effects of silymarin and its active component SB on plasma membrane stability and hepatocellular lysis. Chemico-Biol Interact 179:297-303.http://dx.doi.org/10.1016/j.cbi.2008.12.008

[4] Beutler E (1983), Active transport of glutathione disulfide from erythrocytes. In: Larson A, Orrenius S, Holmgren A, Mannerwik BEDS., eds. Functions of Glutathione, Biochemical, Physiological, Toxicological and Clinical Aspects. New York, NY:Raven Press, 65 .

[5] Bharti VK, Srivastava RS, Anand AK, Kusum K (2012), Buffalo (Bubalusbubalis) epiphyseal proteins give protection from arsenic and fluoride-induced adverse changes in acetylcholinesterase activity in rats. $\mathrm{J}$ Biochem Molecular Toxicology 26: 1015.http://dx.doi.org/10.1002/jbt.20407.

[6] Bloor WR, Pelkan KF, Allen DM (1922), Determination of fatty acids and cholesterol in small amount of blood plasma. J BiolChem 52: 191-205.

[7] Bondy SC (1997),Free radical mediated toxic injury to the nervous system. In: Wallace KB (ed): Free Radical Toxicology, Taylor and Francis, Oxford 221-248.

[8] Brinkel J, Khan MMH, Kraemer A (2009), A systematic review of arsenic exposure and its social and mental health effects with special reference to Bangladesh. Int J Environ Res Public Health 6: 1609-19.http://dx.doi.org/10.3390/ijerph6051609.

[9] Chattopadhyay S, Bhaumik S, Nag Chaudhury A, Das Gupta S (2002),Arsenic-induced changes in growth development and apoptosis in neonatal and adult brain cells in vivo and in tissue culture ToxicolLett 128: 73-84.http://dx.doi.org/10.1016/S0378 4274(01)00535-5.

[10] Das AK, Bag S, Sahu R, Dua TK, Sinha MK, Gangopadhyay M, et al (2010), Protective effect of Corchorusolitorius leaves on sodium arsenite-induced toxicity in experimental rats. Food ChemToxicol 48: 326-35.http://dx.doi.org/10.1016/j.fct.2009.10.020.

[11] Ellman GL, Courtney KD, Andres V, Featherstone RM (1961), A new and rapid colorimetric determination of acetylcholinesterase activity.

BiochemPharmacol7: 95.http://dx.doi.org/10.1016/0006-2952(61)90145-9.

[12] EllmanGL (1959), Tissue sulfhydryl groups. Arch BiochemBiophys 82: 70-77.http://dx.doi.org/10.1016/0003-9861(59)90090-6

[13] Ferenci P, Dragosics B, Dittrich H, Frank H, Benda L, Lochs H, Meryn S, Base W, Schneider B (1989), Randomized controlled tria of silymarin treatment in patients with cirrhosis of the liver. J Hepatol 9: 105-113.http://dx.doi.org/10.1016/0168-8278(89)90083-4.

[14] Flora SJ and Gupta R (2007), beneficial effect of Centellaasiatica aqueous extract against arsenic induced oxidative stress and essential metal status in rats. Phytother Res 21: 980988.http://dx.doi.org/10.1002/ptr.2208.

[15] Flora SJ, Bhatt K, Mehta A (2009), Arsenic moiety in gallium arsenide is responsible for neuronal apoptosis and behavioral alterations in rats. ToxicolApplPharmacol 240: 23644.http://dx.doi.org/10.1016/j.taap.2009.05.013.

[16] Folch J, Ascoli I, Less M, Meath JA et al (1951), Preparation of lipid extracts from brain tissue. J BiolChem 191: 833-41.

[17] Glowinski J, Iverson IL (1966), Regional studies on catecholamines in the rat brain. I. The disposition of $(3 \mathrm{H})$ norepinephrine, $(3 \mathrm{H})$ dopamine and $(3 \mathrm{H})$ dopa in various regions of the rat brain. J Neurochem 13: 665-9.

[18] Gutteridge JMC (1995), Lipid peroxidation and antioxidants as biomarkers of tissue damage. ClinChem41: 1819-1828.

[19] Haider SS,Najar MSA (2008), Arsenic induces oxidative stress, sphingolipidosis, depletes proteins and some antioxidants in various regions of rat brain. Kathmandu University Medical Journal 6 (21) 60-69.

[20] Halliwell B (2006), Oxidative stress and neurodegeneration: Where are we now? J Neurochem 97:1634 1658.http://dx.doi.org/10.1111/j.1471-4159.2006.03907.x.

[21] Horn HD, Burns FH (1978), Assay of glutathione reductase activity. In: Bergmeyer HV ed. Methods of Enzymatic Analysis. New York:Academic Press 142-146.

[22] Hughes MF (2002), Arsenic toxicity and potential mechanisms of action. ToxicolLett 133:1-16.http://dx.doi.org/10.1016/S0378 4274(02)00084-X.

[23] International Agency for Research on Cancer (1989), Overall evaluations of carcinogenicity: an update of IARC monographs. IARC monographs on the evaluation of Carcinogenic Risks to humans 7 : $1-42$
[24] Jones DP (2002), Redox potential of GSH/GSSG couple: assay and biological significance. Methods Enzymol 348: 93 112.http://dx.doi.org/10.1016/S0076-6879(02)48630-2.

[25] Kakkar P, Das B, Viswanathan PN (1984), a modified spectrophotometric assay of superoxide dismutase. Indian J BiochemBiophys 21:130-132.

[26] Kapaj S, Peterson H, Liber K, Bhattacharya P (2006), Human health effects from chronic arsenic poisoning: a review. J Environ Health A41: 2399 428.http://dx.doi.org/10.1080/10934520600873571.

[27] Khan MMH, Aklimunnessa K, Kabir M, Mori M (2006), Case control study of arsenicosis in some arsenic contaminated villages of Bangladesh. Sapporo Med J 75: 51-61.

[28] Kirkman HN and Gaetani GF (1984), Catalase: a tetrameric enzyme with four tightly bound molecules of NADPH. ProcNatlAcadSci USA 81: 4343-4347.http://dx.doi.org/10.1073/pnas.81.14.4343.

[29] Levine RL, Garland D, Oliver CN, Amici A, Climent I, Lenz AG Ahn B, ShaltielS,Stadtman ER (1990), Determination of carbonyl content in oxidatively modified proteins. Methods Enzymol 186 464-478.http://dx.doi.org/10.1016/0076-6879(90)86141-H.

[30] Lowry OH, Rosenberg NJ, Farn AL, Randall RJ (1951), Protein measurement with Folin phenol reagent. J BiolChem 193: 265-75.

[31] Manna P, Sinha M, Sil PC (2008), Arsenic-induced oxidative myocardial injury: protective role of arjunolic acid. Arch Toxicol 82:137-49. http://dx.doi.org/10.1007/s00204-007-0272-8.

[32] Marinetti GV (1962), Chromatographic separation, identification and analysis of phosphatides. J Lipid Res 3:1-12.

[33] Mates JM (2000), Effects of antioxidant enzymes in the molecular control of reactive oxygen species. Toxicology 153: 8384.http://dx.doi.org/10.1016/S0300-483X(00)00306-1.

[34] Mccarty MF (2005), potential utility of natural polyphenols for reversing fat-induced insulin resistance. Med. Hypotheses 64(3): 628 635.http://dx.doi.org/10.1016/j.mehy.2003.11.042.

[35] McCord JM, Keele BB, Fridovich I (1976), an enzyme based theory of obligate anaerobis: the physiological functions of superoxide dismutase. ProcNatlAcadSci, U.S.A 68: 1024 1031.http://dx.doi.org/10.1073/pnas.68.5.1024.

[36] Naso LG, Ferrer EG, Butenko N, Cavaco I, Lezama L, Rojo T, Etcheverry SB, Williams PAM (2011), Antioxidant, DNA cleavage, and cellular effects of silibinin and a new oxovanadium(IV) /silibinin complex. J BiolInorgChem 16:653668.http://dx.doi.org/10.1007/s00775-011-0769-8.

[37] North DW, Gibb HJ, Abernathy CO (1997), as: past, present and future considerations. In: Abernathy CO, Calderon RL, Chappell WR, Eds. As Exposure and Health Effects. London, UK: Chapman and Hall 407-423.

[38] Ohkawa H, Ohishi N, Yagi K (1979), Assay for lipid peroxides in animal tissues by thiobarbituric acid reaction. Anal. Biochem 95 (2): 351-358.http://dx.doi.org/10.1016/0003-2697(79)90738-3.

[39] Omaye ST, Turbull TD, Sauberlich HC (1979), Selected method for the determination of ascorbic acid in animal cells, tissues and fluids. In: McCormic DB, Wright DL, eds. Methods in Enzymology. New York, NY. Academic Press, 3 11.http://dx.doi.org/10.1016/0076-6879(79)62181-x.

[40] Pietrangelo A, Borella F, Casalgrandi G, Montosi G, Ceccarelli D, Gallesi D, Giovannini F, Gasparetto A, Masini A (1995), Antioxidant activity of silybinin vivo during long-term iron overload in rats. Gastroenterology 109: 19411949.http://dx.doi.org/10.1016/0016-5085(95)90762-9.

[41] Pollet S, Ermidou S, Lesaux F, Monge M, and Baumann N (1979), Microanalysis of brain lipids: Multiple two dimensional thin layer chromatography. J Lipid Res 19: 916-21.

[42] Pradhan SC and Girish C (2006), Hepatoprotective herbal drug, Silymarin from experimental pharmacology to clinical medicine. Indian J Med Res 124: 491-504.

[43] Radabaugh TR, Aposhian HV (2000), enzymatic reduction of arsenic compounds in mammalian system: reduction of arsenate to arsenite by human liver arsenate reductase. Chem Res Toxicol 13:2630.http://dx.doi.org/10.1021/tx990115k

[44] Rajnarayana K, Sripalreddy M, Chaluvadi MR, Krishna DR (2001),Bioflavonoids Classification, Pharmacological, Biochemical Effects and Therapeutic Potential. Indian J Pharm 33:2-16.

[45] Rios R, Zarazua S, Santoyo ME, Sepulveda-Saavedra J, RomeroDi'az V, Jimenez V, et al (2009), Decreased nitric oxide markers and morphological changes in the brain of arsenic exposed rats. Toxicology 261: 68-75.http://dx.doi.org/10.1016/j.tox.2009.04.055.

[46] Rosado JL, Ronquillo D, Kordas K, Rojas O, Alatorre J, Lopez P, et al (2007), Arsenic exposure and cognitive performance in Mexican schoolchildren. Environ Health Perspect 115: 13715.http://dx.doi.org/10.1289/ehp.9961. 
[47] Rotruck JT, Pope AL, Ganther HE, Swanson AB, Hafeman DG, Hoekstra WG (1973), Selenium: biochemical role as a component of glutathione peroxidase. Science 179:588590.http://dx.doi.org/10.1126/science.179.4073.588.

[48] Roughan PG, Batt RD (1968), Quantitative analysis of sulfolipids and galactolipids in plant tissues. Anal Biochem 22: 74-88. http://dx.doi.org/10.1016/0003-2697(68)90261-3.

[49] Saller R, Meier R, Brignoli R (2001), the use of silymarin in the treatment of liver diseases. Drugs 61: 20352063.http://dx.doi.org/10.2165/00003495-200161140-00003.

[50] Shila S, Kathirvel R, Jayavelu T, Chinnakkannu P (2005a), Protein oxidative damage in arsenic induced rat brain: influence of DL-alipoic acid. ToxicolLett155: 2734.http://dx.doi.org/10.1016/j.toxlet.2004.08.001.

[51] Shila S, Kokilavani V, Subathra M, Panneerselvam C (2005), Brain regional responses in antioxidant system to alpha-lipoic acid in arsenic intoxicated rat. Toxicology 210: 2536.http://dx.doi.org/10.1016/j.tox.2005.01.003.

[52] Shila S, Subathra M, Devi MA, Panneerselvam C (2005b), Arsenic intoxication-induced reduction of glutathione level and of the activity of related enzymes in rat brain regions: reversal by DL-a-lipoic acid. Arch Toxicol 79: 140-146.http://dx.doi.org/10.1007/s00204004-0614-8.

[53] Shinomol G, Muralidhara (2007), Differential induction of oxidative impairments in brain regions of male mice following subchronic consumption of Khesaridhal (Lathyrussativus) and detoxified khesaridhal. Neurotoxicology28:798806.http://dx.doi.org/10.1016/j.neuro.2007.03.002.

[54] Sinha AK (1972), Colorimetric assay of catalase. Anal Biochem 47:389-394.http://dx.doi.org/10.1016/0003-2697(72)90132-7.

[55] Sinha H, Manna P, Sil PC (2008b), Arjunolic acid attenuates arsenic-induced nephrotoxicity. Pathophysiology 15: $147-$ 156.http://dx.doi.org/10.1016/j.pathophys.2008.03.001.

[56] Travacio M, Polo JM, Liesuy S (2000), Chromium (VI) induces oxidative stress in the mouse brain. Toxicology 150: 137146.http://dx.doi.org/10.1016/S0300-483X(00)00254-7.

[57] Vahidnia A, van der Voet GB, de Wolff FA (2007), Arsenic neurotoxicity: a review. Hum ExpToxicol 26: 82332.http://dx.doi.org/10.1177/0960327107084539.

[58] Wang MJ, Lin WW, Chen HL, Chang YH,Ou HC, Kuo JS, Hong JS, Jeng KC (2002),Silymarin protects dopaminergic neurons against lipopolysaccharide-induced neurotoxicity by inhibiting microglia activation. Eur J NeuroSci 16: 21032112.http://dx.doi.org/10.1046/j.1460-9568.2002.02290.x.

[59] Winterbourn CC (2008), Reconciling the chemistry and biology of reactive oxygen species. Nat ChemBiolWinterbourn, C. C. Reconciling the chemistry and biology of reactive oxygen species. Nat ChemBiol 4: 278-286.http://dx.doi.org/10.1038/nchembio.85.

[60] Woodman DD, Price CP Estimation of serum total lipids (1972), ClinChemActa 38: 39-43. http://dx.doi.org/10.1016/0009 8981(72)90205-7.

[61] Yadav RS, Sankhwar ML, Shukla RK, Chandra R, Pant AB, Islam F, Khanna VK (2009), Attenuation of arsenic neurotoxicity by curcumin in rats. ToxicolApplPharmacol 240: 367376.http://dx.doi.org/10.1016/j.taap.2009.07.017.

[62] Yamanaka K, Hasegawa A, Sawamura R, Okada S (1991), Cellular response to oxidative damage in lung induced by administration of dimethyl arsenic acid, a major metabolite of inorganic arsenic in mice. ToxicolApplPharmacol 108: 205 213.http://dx.doi.org/10.1016/0041-008X(91)90111-Q.

[63] Yoshida T, Yamauchi H, Sun G (2004) chronic health effects in people exposed to arsenic via the drinking water: dose-response relationships in review. ToxicolApplPharmacol 198: 243252.http://dx.doi.org/10.1016/j.taap.2003.10.022.

[64] Zarazua S, Perez-Severiano F, Delgado JM, Martinez LM, OrtizPerez D, Jimenez-Capdeville ME (2006), Decreased nitric oxide production in the rat brain after chronic exposure arsenic exposure. Neurochem Res31: 1069-77.http://dx.doi.org/10.1007/s11064-0069118-7. 